\title{
Journal of Environmental Analytical

\section{Thermodynamic Study of the Competitive Adsorption of Chromium (III) Ions and Halides onto Sweet Orange (Citrus Sinensis) Peels as Adsorbent}

\author{
Ayuba A Muhammad ${ }^{1}$, Ugbe F Audu ${ }^{2}$, Adamu S Onakpa ${ }^{2}$ and Aloysius A Pam ${ }^{2 *}$ \\ ${ }^{1}$ Department of Pure and Industrial Chemistry, Bayero University, Kano, Nigeria \\ ${ }^{2}$ Department of Chemistry, Federal University, Lokoja, Nigeria
}

*Corresponding author: Pam alosyius, Department of Chemistry, Federal University, Lokoja, Nigeria, Tel: +234(64)661480; E-mail: aloysiuspam@yahoo.com

Rec date: 06 July, 2014, Acc date: 31 July, 2014, Pub date: 02 August, 2014

Copyright: (c) 2014 Muhammad AA, et al. This is an open-access article distributed under the terms of the Creative Commons Attribution License, which permits unrestricted use, distribution, and reproduction in any medium, provided the original author and source are credited.

\begin{abstract}
The combined adsorption of $\mathrm{Cr}$ (III) ions and halides from aqueous solution using orange peels as adsorbent was modeled. Orange peels as adsorbent is resource-saving, and has environmental friendly behavior. The influence of initial $\mathrm{pH}$, initial solution ion concentration, adsorbent dosage, halides and temperature on the adsorption efficiency was studied using batch equilibrium assays. Results showed that, adsorption of $\mathrm{Cr}$ (III) ions increases with decrease in initial $\mathrm{pH}$ (maximum at 2), increasing initial solution concentration, increasing peels dosage, absence of halides and decreasing temperature. Among the tested isotherm models, the Freundlich isotherm best modeled both adsorptions without and with presence of halides. Some thermodynamic parameters; $\Delta \mathrm{G}, \Delta \mathrm{H}, \mathrm{A}, \Delta \mathrm{H}_{\mathrm{r}}$ and $\Delta \mathrm{S}$ were calculated from the experimental data, with the result showing that the adsorption process is feasible, spontaneous and follow physisorption mechanism. Thus, orange peel is effective in the sorption of chromium (III) ions from aqueous solution.
\end{abstract}

Keywords: Adsorption; Chromium; Halides; Isotherms; Orange peels; Thermodynamic parameters

\section{Introduction}

The problems of the ecosystem are increasing with developing technology; heavy metals pollution is one of the main problems [1]. Toxic metal compounds coming to the earth's surface not only reach the earth's Waters (seas, lakes, ponds and reservoirs), but can also contaminate underground water in trace amounts by leaking from the soil after rain and snow. Therefore, the earth's waters may contain various toxic metals [1]. Water pollution raises a great concern nowadays since water constitutes a basic necessity in life and thus, is essential to all living things. In developing countries such as Nigeria, industries such as metal mining operations, fertilizers and paper industries and pesticides majorly contribute to the pollution of the ecosystem through the discharge of industrial effluents into the water system. Water contamination by heavy metals is more pronounced than other pollutants exposed to the natural ecosystem. "Heavy metals" refers to any element with atomic number between 63.5 and 200.6 and a specific gravity greater than $5.0[1,2]$.

Heavy metals are non-biodegradable and can lead to accumulation in living organisms, causing various diseases and disorders [3]. It is well known that some metals are harmful to life, such as antimony, chromium, copper, lead, manganese, mercury, cadmium, etc., and are significantly toxic to human beings and the ecological environments [4]. Therefore, studies on the removal of heavy metal(s) pollution are increasingly challenging [1]. One of such methods is the use of adsorption technique. Interest has recently risen in the investigation of some unconventional methods and low cost materials for scavenging heavy metal ions from industrial waste waters [5]. In general, an adsorbent can be assumed as "low cost" if it requires little processing, is abundant in nature, or is a by-product or waste material from the industry [3].
Many researchers had worked on chromium and its effect on environment most especially when it is discharged through an industrial effluent. Dhungana et al. [6] observed the determination of chromium in tannery effluent. The adsorption of $\mathrm{Cr}$ (VI) on saw dust and charcoal from sugar cane bagasses by spectrophotometric method was conducted using diphenylcarbazide as a color developing reagent to analyze the chromium content in tannery effluent located in Bara and Parsa districts of Nepal. According to Cavaco et al. [7] who carried out the removal of chromium in industrial effluent using ion exchange resins, effluent discharged from the chromium electroplating industry containing large number of metals, including chromium, copper, nickel and zinc, found that the ion exchange process is an alternative technique for application in the treatment of industrial waste water containing heavy metals.

The purpose of this study among others was to investigate the removal of Chromium (III) ions and halides from aqueous solution by adsorption, to determine the optimum removal condition using Orange peels (low cost adsorbent), to determine the suitable adsorption isotherms and their related thermodynamic and physical constants.

\section{Materials and Methods}

In the preparation of reagents, chemicals of analytical grade purity and distilled water were used. All apparatus were thoroughly washed with detergent solution followed by tap water and lastly, distilled water was used for the rinsing. Throughout the course of this work, distilled water was used significantly. The following reagents were used for the laboratory work: Hydrochloric acid $(\mathrm{HCl})$, Sodium hydroxide $(\mathrm{NaOH})$, Sodium nitrate $\left(\mathrm{NaNO}_{3}\right)$, Chromium nitrate nonahydrate $\left(\mathrm{Cr}\left(\mathrm{NO}_{3}\right)_{3} \cdot 9 \mathrm{H}_{2} \mathrm{O}\right)$, Nitric acid $\left(\mathrm{HNO}_{3}\right)$, Potassium Chloride $(\mathrm{KCl})$, Potassium Iodide (KI) and Potassium Bromide (KBr). 
Citation: Pam AA, Audu UF, Onakpa SA, Muhammad AA (2014) Thermodynamic Study of the Competitive Adsorption of Chromium (III) lons and Halides onto Sweet Orange (Citrus Sinensis) Peels as Adsorbent. J Environ Anal Chem 1: 114. doi:10.4172/JREAC.1000114

Page 2 of 7

\section{Sample collection/pretreatment}

The adsorbent of interest in this work is powdered orange peels. The sample was collected from orange traders along Kabuga-Gwarzo road, Kano State, Nigeria. The freshly collected samples were washed, air-dried, ground and screened to pass through a $1 \mathrm{~mm}$ analytical sieve to remove larger particles. The sieved sample was then labeled and put inside a polythene bag and stored in air-tight for further use as the adsorbent [8].

\section{Adsorption envelopes experiments}

Adsorption experiments were carried out at different $\mathrm{pH}$ so as to ascertain the $\mathrm{pH}$ at which maximum adsorption was to be obtained. Adsorbent dosage of $2.5 \mathrm{~g}, \mathrm{Cr}\left(\mathrm{NO}_{3}\right)_{3} .9 \mathrm{H}_{2} \mathrm{O}(1 \mathrm{~g}), \mathrm{NaNO}_{3}\left(25 \mathrm{~cm}^{3}, 0.1\right.$ $\mathrm{M})$ differently at $\mathrm{pH}(2,4,6,9$ and 12$)$ respectively were added into five different centrifuge tubes $\left(50 \mathrm{~cm}^{3}\right)$ with each tube conditioned at a different $\mathrm{pH}$. The tubes were placed in a reciprocating shaker at $30^{\circ} \mathrm{C}$ and shaken for four hours. The content of the tubes were centrifuged and filtered into labeled polythene bottles which were analyzed using the Atomic Absorption Spectrophotometer (Buckmann Model 4) to determine the concentration of the residual (un-adsorbed) Chromium. The same procedure was used for the competitive adsorption of Chromium and halides $(0.186 \mathrm{~g} \mathrm{KCl}, 0.323 \mathrm{~g} \mathrm{KBr}$ and $0.415 \mathrm{~g} \mathrm{KI})$ to each tube $[9,10]$.

\section{Adsorption isotherm experiments}

This experiment been temperature sensitive was conducted differently at $30^{\circ} \mathrm{C}, 40^{\circ} \mathrm{C}$ and $50^{\circ} \mathrm{C}$ respectively. Adsorbent dosage of 1 $\mathrm{g}, 1.5 \mathrm{~g}$ and $2 \mathrm{~g}$ were added differently into three different polypropylene centrifuge tubes $\left(50 \mathrm{~cm}^{3}\right)$. To each tube, $\mathrm{NaNO}_{3}(25$ $\mathrm{cm}^{3}, 0.1 \mathrm{M}$ ) at a $\mathrm{pH}$ of 2 (obtained as optimum $\mathrm{pH}$ from adsorption envelope) was added to obtain an ionic strength. Each solution was then allowed to equilibrate for a period of 24hours (1day). After equilibration, $\mathrm{Cr}\left(\mathrm{NO}_{3}\right)_{3} .9 \mathrm{H}_{2} \mathrm{O}(1 \mathrm{~g}, 0.1 \mathrm{M})$ was added to each tube and then shaken for a period of 4 hours differently at $30^{\circ} \mathrm{C}, 40^{\circ} \mathrm{C}$ and $50^{\circ} \mathrm{C}$ respectively. The content of the tubes were then centrifuged at a relative centrifugal force of 8000 revolutions per minute ( $\mathrm{RCF}=7649 \mathrm{xg}$ ) for 20 minutes. The decantate was filtered and the solution was analyzed using Atomic Absorption Spectrophotometer (Buckmann Model 4) to determine the concentration of the residual (un-adsorbed) Chromium. The same procedure was utilized for $0.2 \mathrm{M}$ and $0.3 \mathrm{M}$ Chromium and also for the competitive adsorption of Chromium $(0.1 \mathrm{M}, 0.2 \mathrm{M}, 0.3 \mathrm{M})$ and halides $(0.186 \mathrm{~g} \mathrm{KCl}, 0.323 \mathrm{~g}$ $\mathrm{KBr}$ and $0.415 \mathrm{~g} \mathrm{KI}$ ) respectively [11].

The removal efficiency (percentage adsorption) of chromium ions (analyte) from aqueous solution was determined using the formulae in Eq. (1)

$$
\% \text { ad }=\left[\frac{C 0-C f}{C 0}\right] X 100(1)
$$

Where, $\mathrm{C} 0=$ the concentration of analyte before adsorption and $\mathrm{Cf}=$ the concentration after adsorption in $\mathrm{mol} / \mathrm{L}$ or $\mathrm{mg} / \mathrm{L}$ [12].

\section{Results and Discussion}

The various data generated from the experiment were analyzed and the results presented with discussion as follows:

\section{Effect of initial pH (adsorption envelope)}

In order to ascertain the $\mathrm{pH}$ at which the maximum adsorption of $\mathrm{Cr}$ (III) ions from aqueous solution occur, several experiments were carried out at $\mathrm{pH}$ of $2,4,7,9$, and 12 using $2.5 \mathrm{~g}$ powdered orange peel (as adsorbent) at a constant temperature of $30^{\circ} \mathrm{C}$. It was observed that the adsorption process is dependent on $\mathrm{pH}$. The percentage adsorption was found to increase with decrease in test solution absorbance value. It was also observed that increase in the initial $\mathrm{pH}$ resulted to a decrease in percentage Chromium adsorption onto the adsorbent with the optimal adsorption occurring at $\mathrm{pH}$ of 2 for both Chromium and Chromium-halide competitive systems (Table 1). Further observation showed that the percentage Chromium adsorption was higher in the absence of halides at all tested $\mathrm{pH}$ values (Table 1). This could be associated to the reason that; of the three most common forms of chromium; $\mathrm{Cr}(\mathrm{II}), \mathrm{Cr}(\mathrm{III})$ and $\mathrm{Cr}(\mathrm{VI})$, the $\mathrm{Cr}(\mathrm{III})$ is more common at low $\mathrm{pH}$ in form of $\left[\mathrm{Cr}(\mathrm{OH})_{6}\right]^{3-}$ in aqueous solution. Sweet Orange peel is an oxygen containing material. Since oxygen contains lone pair of electrons, it can easily be protonated in strong acidic solution. With the protonated groups present on the surface of the adsorbent at low $\mathrm{pH}$, the negatively charged $\left[\mathrm{Cr}(\mathrm{OH})_{6}\right]^{3-}$ can easily be attracted by the positively protonated adsorbent surface, thereby increasing the adsorption tendencies of $\mathrm{Cr}$ (III) to the adsorbent surface as $\mathrm{pH}$ drops $[13,14]$.

\begin{tabular}{|l|l|l|}
\hline pH & \% Adsorption (Without Halides) & \% Adsorption (With Halides) \\
\hline 2 & 81 & 79 \\
\hline 4 & 77 & 73 \\
\hline 7 & 70 & 66 \\
\hline 9 & 68 & 64 \\
\hline 12 & 63 & 59 \\
\hline
\end{tabular}

Table 1: Percent Adsorption of Chromium at Various Aqueous Systems at varying $\mathrm{pH}$

\section{Adsorption isotherm models}

The equilibrium models that was used in describing the adsorption isotherms for this research include; Linear, Freundlich, Langmuir and Temkin isotherm models. Their mathematical expressions are as follows;

\section{Linear isotherm}

$\mathrm{S}=\mathrm{KdC} \ldots \ldots \ldots \ldots(2)$

Where $\mathrm{S}=$ adsorptiondensity of Chromium in the solid phase $(\mu \mathrm{g}$ $\left.\mathrm{g}^{-1}\right), \quad \mathrm{K}_{\mathrm{d}}=$ distribution coefficient $\left(\mathrm{ml} \mathrm{g}^{-1}\right), \mathrm{C}=$ concentration of Chromium in solution $\left(\mu \mathrm{g} \mathrm{mL} \mathrm{m}^{-1}\right)$.

\section{Freundlich isotherm}

$$
\log \mathrm{S}=\log \mathrm{K}+1 / \mathrm{n} \log \mathrm{C}
$$

Where $\mathrm{S}=$ concentration of Chromium retained by adsorbent, $\mathrm{mg} / \mathrm{kg}$ or $\mathrm{mol} / \mathrm{kg}, \mathrm{C}=$ concentration of Chromium in solution, $\mathrm{mg} / \mathrm{L}$ or $\mathrm{mol} / \mathrm{L}, \mathrm{K}$ is a curve fitting parameter for equilibrium model, $\mathrm{n}=$ adsorption intensity [15]. 
Citation: Pam AA, Audu UF, Onakpa SA, Muhammad AA (2014) Thermodynamic Study of the Competitive Adsorption of Chromium (III) lons and Halides onto Sweet Orange (Citrus Sinensis) Peels as Adsorbent. J Environ Anal Chem 1: 114. doi:10.4172/JREAC.1000114

Page 3 of 7

\section{Langmuir isotherm}

$(\mathrm{C} / \mathrm{S})=(1 / \mathrm{Kb})+(\mathrm{C} / \mathrm{b})$

Where $\mathrm{S}=$ concentration of Chromium retained by adsorbent, $\mathrm{mg} / \mathrm{kg}$ or $\mathrm{mol} / \mathrm{kg}, \mathrm{C}=$ concentration of Chromium in solution, $\mathrm{mg} / \mathrm{L}$ or $\mathrm{mol} / \mathrm{L}, \mathrm{K}$ is a curve fitting parameter for equilibrium model, $\mathrm{b}$ is a stoichiometric coefficient [15].

\section{Temkin isotherm}

$$
\mathrm{X}=\mathrm{a}+\mathrm{b} \ln \mathrm{C}
$$

Where $\mathrm{C}=$ Concentration of Chromium in solution at equilibrium $(\mathrm{mg} / \mathrm{L}), \quad \mathrm{X}=$ Amount of Chromium adsorbed per unit weight of adsorbent $(\mathrm{mg} / \mathrm{gm}), \mathrm{a}$, and $\mathrm{b}$ are constants related to adsorption capacity and intensity of adsorption.

The goodness of fit of the experimental data was measured by the correlation coefficient, $\mathrm{R}^{2}$ at $30^{\circ} \mathrm{C}, 40^{\circ} \mathrm{C}$ and $50^{\circ} \mathrm{C}$. At all the temperatures tested, Freundlich isotherm showed better fit for adsorption without and with presence of halides as shown in Table 2 below. Figures 1-6 present the Freundlich Isotherm plots.

\begin{tabular}{|l|l|l|l|l|l|l|}
\hline \multirow{2}{*}{$\begin{array}{l}\text { Isotherm } \\
\text { Model }\end{array}$} & \multicolumn{3}{|l|}{$30^{\circ} \mathrm{C}$} & \multicolumn{2}{l|}{$40^{\circ} \mathrm{C}$} & \multicolumn{2}{l|}{$50^{\circ} \mathrm{C}$} & \multicolumn{2}{l|}{$\begin{array}{l}\text { Withou } \\
\text { Halide }\end{array}$} & $\begin{array}{l}\text { With } \\
\text { Halide }\end{array}$ & $\begin{array}{l}\text { Without } \\
\text { Halide }\end{array}$ & $\begin{array}{l}\text { With } \\
\text { Halide }\end{array}$ & $\begin{array}{l}\text { Without } \\
\text { Halide }\end{array}$ & With Halide \\
\hline Linear & 0.83 & 0.845 & 0.803 & 0.843 & 0.792 & 0.858 \\
\hline $\begin{array}{l}\text { Langmui } \\
\mathrm{r}\end{array}$ & 0.687 & 0.942 & 0.699 & 0.943 & 0.707 & 0.947 \\
\hline \multirow{2}{*}{$\begin{array}{l}\text { Freundlic } \\
\mathrm{h}\end{array}$} & 0.912 & 0.948 & 0.911 & 0.937 & 0.897 & 0.955 \\
\cline { 2 - 7 } & $\mathrm{n}=0.6$ & $\begin{array}{l}\mathrm{n}=0.4 \\
9\end{array}$ & $\mathrm{n}=0.6$ & $\mathrm{n}=0.43$ & $\mathrm{n}=0.55$ & $\mathrm{n}=0.39$ \\
\hline Temkin & 0.777 & 0.793 & 0.78 & 0.779 & 0.747 & 0.7 \\
\hline
\end{tabular}

Table 2: Values of Correlation Coefficient $\left(\mathrm{R}^{2}\right)$ for the Adsorption Isotherm Models of Chromium onto Orange Peels in the Presence and Absence of Halides at Various Temperatures. (Key: $\mathrm{n}=$ adsorption intensity),

If $\mathrm{n}$ is greater than unity, it indicates chemisorptions. Isotherms with $\mathrm{n}>1$ are classified as L-type isotherms reflecting a high affinity between adsorbate and adsorbent and indicative of chemisorptions $[16,17]$.

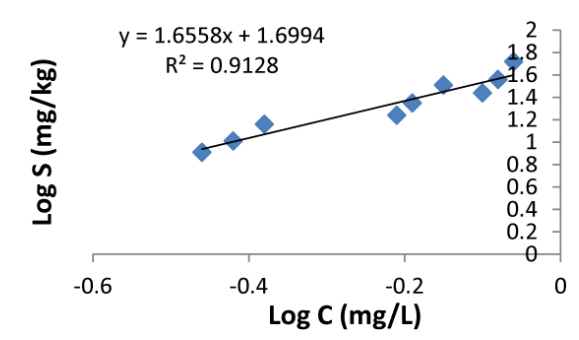

Figure 1: Freundlich isotherm model for adsorption without halides at $30^{\circ} \mathrm{C}$.

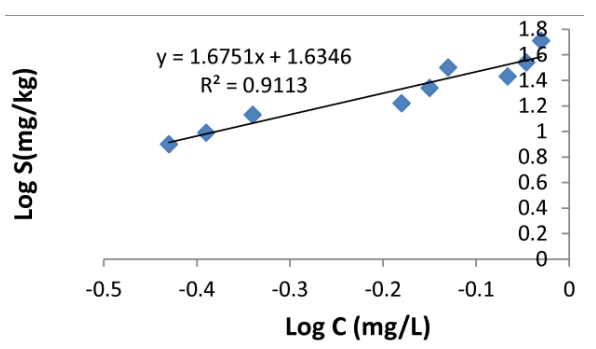

Figure 2: Freundlich isotherm model for adsorption without halides at $40^{\circ} \mathrm{C}$.

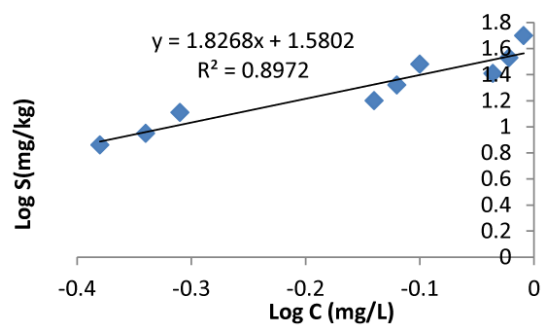

Figure 3: Freundlich isotherm model for adsorption without halides at $50^{\circ} \mathrm{C}$.

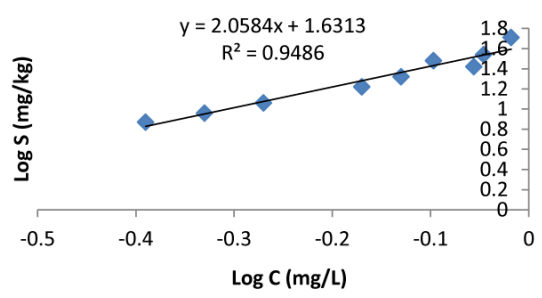

Figure4: Freundlich isotherm model for adsorption with halides at $30^{\circ} \mathrm{C}$.

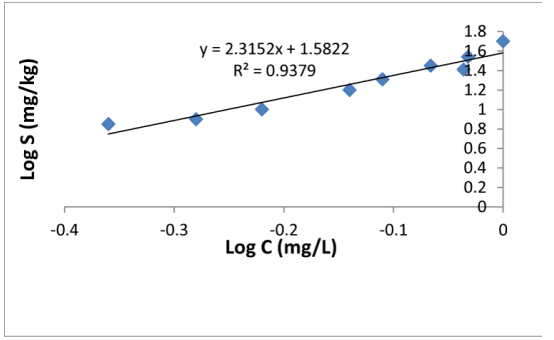

Figure 5: Freundlich isotherm model for adsorption with halides at $40^{\circ} \mathrm{C}$. 
Citation: Pam AA, Audu UF, Onakpa SA, Muhammad AA (2014) Thermodynamic Study of the Competitive Adsorption of Chromium (III) lons and Halides onto Sweet Orange (Citrus Sinensis) Peels as Adsorbent. J Environ Anal Chem 1: 114. doi:10.4172/JREAC.1000114

Page 4 of 7

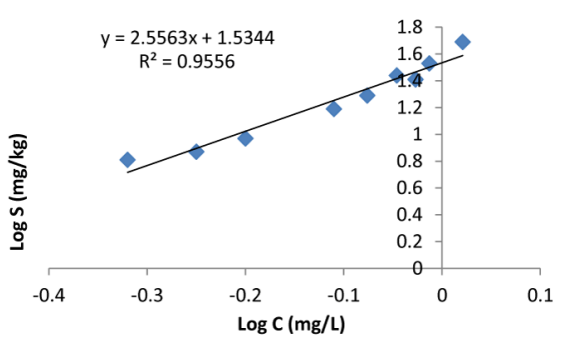

Figure 6: Freundlich isotherm model for adsorption with halides at $50^{\circ} \mathrm{C}$.

In this work, the values of $\mathrm{n}$ are less than unity indicating physisorption. It can be concluded that since the experimental data best obeyed Freundlich isotherm and adsorption is physisorption, the adsorption is a typical multilayer and that the surface of the orange peel is heterogeneous [18].

\section{Thermodynamic parameters and the effect of temperature}

The changes of enthalpy, entropy, isosteric heats of adsorption and Gibb's free energy, and the pre-exponential factor were all calculated from the data generated from the experiments using the following equations and were presented in Tables 3 and 4.

\section{Arrhenius equation}

The effect of temperature on Chromium ion adsorption by the orange peels can be examined in greater detail by applying the Arrhenius equation on the rate constant data. The mathematical expression of the Arrhenius equation is

$\mathrm{k}=\mathrm{Ae}-\mathrm{Ea} / \mathrm{RT}$ or $\ln \mathrm{k}=\ln \mathrm{A}-\mathrm{Ea} / \mathrm{RT}$.

Where $k$ is the rate constant, defined as

$\mathrm{k}=\mathrm{C}_{\mathrm{S}} / \mathrm{C}_{\mathrm{b}}$

Where $\mathrm{C}_{\mathrm{S}}=$ concentration of analyte adsorbed on the surface of the adsorbent at equilibrium and $\mathrm{C}_{\mathrm{b}}=$ concentration of analyte in bulk solution at equilibrium

$A$ is the pre-exponential factor (frequency factor), which is a measure of the accessibility of the reaction sites to Chromium, $E_{a}$ is the Arrhenius activation energy, which must be overcome before adsorption can take place, $\mathrm{R}$ is the universal gas constant and $\mathrm{T}$ is the absolute temperature.

A plot of $\ln k$ (on the y-axis) and $1 / T$ (on the $\mathrm{x}$-axis) yielded a straight line, from which A was obtained based on the intercept value $[19,20]$. Some of the Arrhenius plots for various adsorbent-dose/ analyte-concentration systems are presented in figures (7-12).

The values of $\mathrm{k}$ from the plots, increases with temperature decrease. Since adsorption capacity increases with increasing $\mathrm{k}$, it can therefore be concluded that the adsorption capacity decreases with increasing temperature for the same mass of adsorbent and analyte concentration. The decrease was due to weak adsorptive forces between the active sites and the adsorbed species and also between close by molecules of adsorbed phase. This suggests that the adsorption process is physisorption [13].

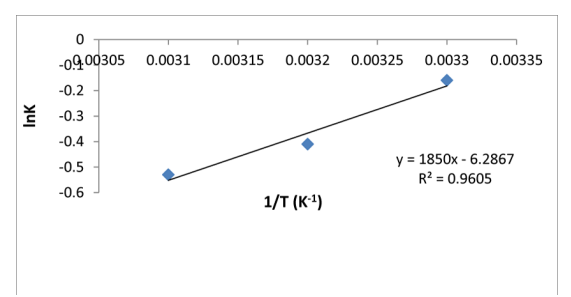

Figure 7: Effect of temperature on adsorption for $1 \mathrm{~g} / 0.1 \mathrm{M}$ adsorbent/analyte with halides.

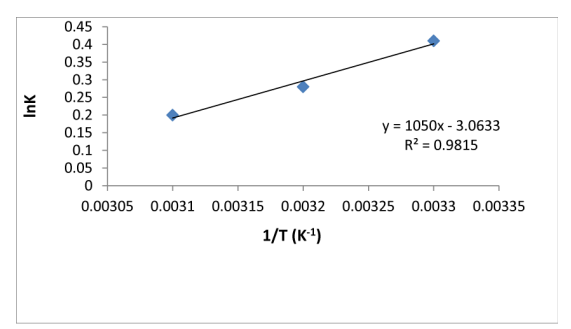

Figure 8: Effect of temeperature on adsorption for $1 \mathrm{~g} / 0.2 \mathrm{M}$ adsorbent/analyte with halides.

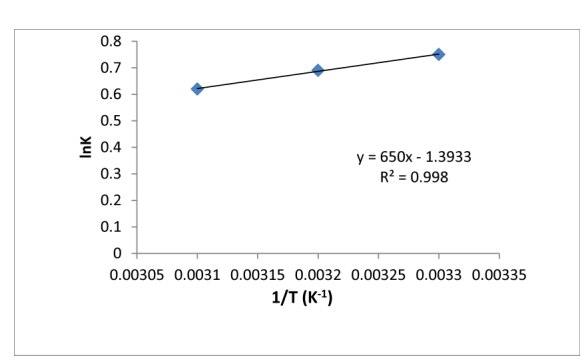

Figure9: Effect of temperature on adsorption for $1 \mathrm{~g} / 0.3 \mathrm{M}$ adsorbent/analyte with halides.

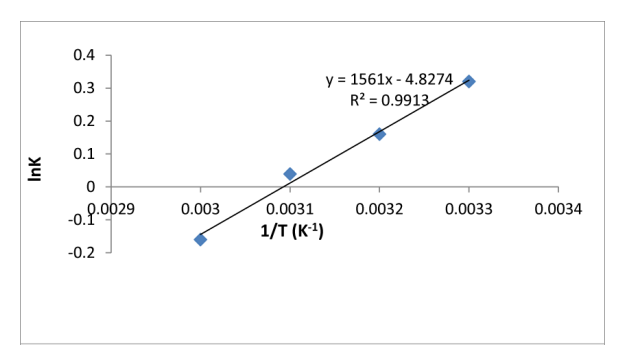

Figure10: Effect of temperature on adsorption for $1 \mathrm{~g} / 0.1 \mathrm{M}$ adsorbent/analyte without halides. 
Citation: Pam AA, Audu UF, Onakpa SA, Muhammad AA (2014) Thermodynamic Study of the Competitive Adsorption of Chromium (III) lons and Halides onto Sweet Orange (Citrus Sinensis) Peels as Adsorbent. J Environ Anal Chem 1: 114. doi:10.4172/JREAC.1000114

Page 5 of 7

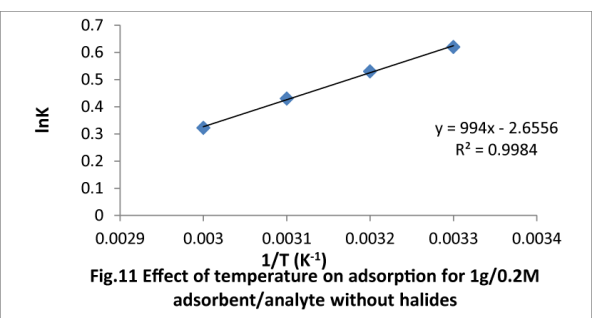

Figure 11: Effect of temperature on adsorption for $1 \mathrm{~g} / 0.2 \mathrm{M}$ adsorbent/analyte without halides.

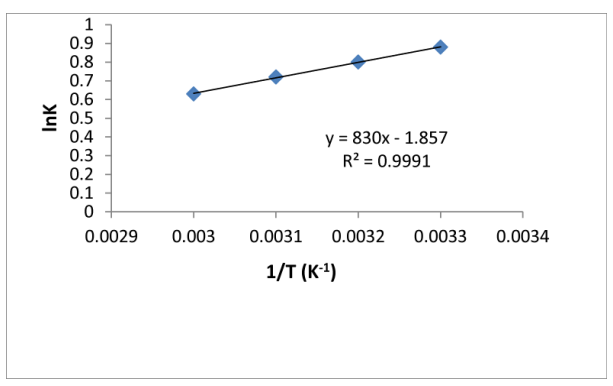

Figure 12: Effect of temperature on adsorption for $1 \mathrm{~g} / 0.3 \mathrm{M}$ adsorbent/analyte without halides.

\section{Clausius-clapeyron equation}

The determination of the isosteric heats of adsorption $\left(\Delta \mathrm{H}_{\mathrm{r}}\right)$ as a function of adsorption density can also provide a clue to the uniformity or non-uniformity of adsorbent surface sites. The isosteric heats of adsorption were calculated from adsorption isotherms at 2 temperatures $\left(30^{\circ} \mathrm{C}\right.$ and $\left.40^{\circ} \mathrm{C}\right)$ using the Clausius-Clapeyron equation thus:

$$
\Delta \mathrm{Hr}=\mathrm{R} \ln [\mathrm{C} 2 / \mathrm{C} 1] /\left(1 / \mathrm{T}_{2}-1 / \mathrm{T}_{1}\right) .
$$

Where $\Delta \mathrm{H}_{\mathrm{r}}$ is the isosteric heat of adsorption at a given adsorption density, $\mathrm{R}$ is the gas constant, $\mathrm{C}_{2}$ is the equilibrium concentration of the Chromium ions at temperature $\mathrm{T}_{2}$ at the given adsorption density, $\mathrm{C}_{1}$ is the equilibrium concentration of the Chromium ions at temperature $\mathrm{T}_{1}$ at the same adsorption density.

If the isosteric heat of adsorption is independent of adsorption density, then the surface is homogenous. But if the isosteric heat of adsorption decreases with increasing adsorption density, then the surface is heterogeneous [21]. Also, if isosteric heat of adsorption is > $40 \mathrm{~kJ} / \mathrm{mol}$, the process is chemisorptions and when less than $8 \mathrm{~kJ} / \mathrm{mol}$, it indicates the adsorption is physical in nature [22].

The enthalpy change $\Delta \mathrm{H}$ for adsorption was calculated using Van't Hoff s equation:

$\mathrm{d}(\ln \mathrm{KC}) / \mathrm{dT}=\Delta \mathrm{H} / \mathrm{RT}_{2}$ which upon integration yields:

$\ln K C=-\Delta H / R T+C$

Where $\mathrm{C}$ is a constant and $\Delta \mathrm{H}$ does not change with temperature. Values of $\Delta \mathrm{H}$ were computed from the slope of the linear variation of $\ln K C$ with $1 / T$.
The thermodynamic parameter, Gibb's free energy change $\Delta G$ is related to equilibrium constant $\mathrm{KC}$ by the equation:

$$
\Delta \mathrm{G}=-\mathrm{RT} \ln K \mathrm{C} \text {. }
$$

Where $\mathrm{R}$ is the gas constant, $\mathrm{T}$ is the absolute temperature; $\mathrm{KC}$ is the concentration equilibrium constant. This relationship has been found to be satisfactory for calculating the Gibb's free energy changes involved in adsorption for low concentration systems. The change of free energy for physisorption is generally between -20 and $0 \mathrm{~kJ} \mathrm{~mol}^{-1}$, the physisorption together with chemisorption is at the range of -20 to $-80 \mathrm{~kJ} \mathrm{~mol}^{-1}$ and chemisorptions is at a range of -80 to $-400 \mathrm{~kJ} \mathrm{~mol}^{-1}$ [23].

From table 3, enthalpy of adsorption was negative and tends towards spontaneity for both systems. The negative values of the enthalpy change indicated that the adsorption process is exothermic and these values also indicated that the adsorption followed a physisorption mechanism involving weak forces of attraction between the adsorbed Chromium/halide ions and orange peels, thereby demonstrating that the adsorption process is stable energetically [23]. The isosteric heat of adsorption $\left(\Delta \mathrm{H}_{\mathrm{r}}\right)$, is not independent of adsorption density and has all its values less than $8 \mathrm{~kJ} / \mathrm{mol}$, hence the surface was proposed to be heterogeneous [21,22]. The negative entropy change $(\Delta S)$ values obtained for all systems correspond to less randomness at the solid/solution interface during the adsorption of Chromium ions and halide ions onto orange peels. Higher values and lower values of the pre-exponential factor $\mathrm{A}$; indicated greater and lesser accessibility of the Chromium ions to the adsorption sites

\begin{tabular}{|c|c|c|c|c|c|c|c|c|}
\hline \multirow{2}{*}{$\begin{array}{l}\text { System } \\
\text { Adsorbent } \\
\text { dose/conc. } \\
\mathrm{Cr}\left(\mathrm{NO}_{3}\right)_{3} .9 \\
\mathrm{H}_{2} \mathrm{O}\end{array}$} & \multicolumn{2}{|c|}{$\Delta \mathrm{S}(\mathrm{kJ} / \mathrm{mol} / \mathrm{K})$} & & & \multicolumn{2}{|c|}{$\Delta \mathrm{H}_{\mathrm{r}}(\mathrm{kJ} / \mathrm{mol})$} & \multicolumn{2}{|c|}{$\Delta \mathrm{H}(\mathrm{KJ} / \mathrm{mol})$} \\
\hline & $\begin{array}{l}\text { Withou } \\
t \\
\text { Halide }\end{array}$ & $\begin{array}{l}\text { With } \\
\text { Halid } \\
\mathrm{e}\end{array}$ & $\begin{array}{l}\text { Withou } \\
t \\
\text { Halide }\end{array}$ & $\begin{array}{l}\text { With } \\
\text { Hali } \\
\text { de }\end{array}$ & $\begin{array}{l}\text { Withou } \\
\mathrm{t} \\
\text { Halide }\end{array}$ & $\begin{array}{l}\text { With } \\
\text { Hali } \\
\text { de }\end{array}$ & $\begin{array}{l}\text { Withou } \\
t \\
\text { Halide }\end{array}$ & $\begin{array}{l}\text { With } \\
\text { Hali } \\
\text { de }\end{array}$ \\
\hline $1.0 \mathrm{~g} / 0.1 \mathrm{M}$ & -0.04 & $\begin{array}{l}-0.05 \\
2\end{array}$ & 0.008 & $\begin{array}{l}0.00 \\
19\end{array}$ & -7.56 & $\begin{array}{l}-8.7 \\
6\end{array}$ & -12.98 & $\begin{array}{l}-15 \\
38\end{array}$ \\
\hline $1.0 \mathrm{~g} / 0.2 \mathrm{M}$ & -0.022 & $\begin{array}{l}-0.02 \\
5\end{array}$ & 0.07 & $\begin{array}{l}0.04 \\
7\end{array}$ & -4.62 & $\begin{array}{l}-6.0 \\
1\end{array}$ & -8.26 & $\begin{array}{l}-8.7 \\
3\end{array}$ \\
\hline $1.0 \mathrm{~g} / 0.3 \mathrm{M}$ & -0.015 & $\begin{array}{l}-0.01 \\
2\end{array}$ & 0.156 & 0.25 & -4.59 & $9^{-3.3}$ & -6.90 & -5.4 \\
\hline $1.5 \mathrm{~g} / 0.1 \mathrm{M}$ & -0.042 & -0.06 & 0.0066 & $\begin{array}{l}0.00 \\
07\end{array}$ & -6.32 & $\begin{array}{l}-8.4 \\
1\end{array}$ & -13.91 & $\begin{array}{c}-18 . \\
71\end{array}$ \\
\hline $1.5 \mathrm{~g} / 0.2 \mathrm{M}$ & -0.025 & $\begin{array}{l}-0.02 \\
4\end{array}$ & 0.05 & $\begin{array}{l}0.05 \\
4\end{array}$ & -6.16 & $8^{-4.3}$ & -9.39 & $3^{-8.7}$ \\
\hline $1.5 \mathrm{~g} / 0.3 \mathrm{M}$ & -0.017 & $\begin{array}{l}-0.00 \\
8\end{array}$ & 0.137 & 0.38 & -6.73 & $\begin{array}{l}-2.7 \\
3\end{array}$ & -7.4 & $\begin{array}{l}-4.5 \\
7\end{array}$ \\
\hline $2.0 \mathrm{~g} / 0.1 \mathrm{M}$ & -0.041 & $\begin{array}{l}-0.03 \\
5\end{array}$ & 0.007 & $\begin{array}{l}0.01 \\
4\end{array}$ & -4.62 & $\begin{array}{l}-5.8 \\
7\end{array}$ & -14.15 & $\begin{array}{l}-11 . \\
64\end{array}$ \\
\hline $2.0 \mathrm{~g} / 0.2 \mathrm{M}$ & -0.024 & $\begin{array}{l}-0.02 \\
1\end{array}$ & 0.056 & $\begin{array}{l}0.08 \\
5\end{array}$ & -6.55 & $\begin{array}{l}-4.7 \\
5\end{array}$ & -9.31 & $0^{-7.9}$ \\
\hline $2.0 \mathrm{~g} / 0.3 \mathrm{M}$ & -0.016 & $\begin{array}{l}-0.00 \\
64\end{array}$ & 0.142 & 0.46 & -7.06 & -3.7 & -7.48 & $6^{-4.1}$ \\
\hline
\end{tabular}
respectively.

Table 3: Some thermodynamic parameters for the adsorption of chromium onto orange peels as adsorbent. 
Citation: Pam AA, Audu UF, Onakpa SA, Muhammad AA (2014) Thermodynamic Study of the Competitive Adsorption of Chromium (III) lons and Halides onto Sweet Orange (Citrus Sinensis) Peels as Adsorbent. J Environ Anal Chem 1: 114. doi:10.4172/JREAC.1000114

Page 6 of 7

From table 4, the overall standard free energy changes during the adsorption process were negative for most systems for the experimental range of temperatures, with range of values corresponding to a spontaneous and a physisorption process [23].

\begin{tabular}{|c|c|c|c|c|c|c|}
\hline \multirow{2}{*}{$\begin{array}{l}\text { System } \\
\text { Adsorbent dose/conc } \\
\mathrm{Cr}(\mathrm{NO3}) 3.9 \mathrm{H} 2 \mathrm{O}\end{array}$} & \multicolumn{2}{|l|}{$30^{\circ} \mathrm{C}$} & \multicolumn{2}{|l|}{$40^{\circ} \mathrm{C}$} & \multicolumn{2}{|l|}{$50^{\circ} \mathrm{C}$} \\
\hline & $\begin{array}{l}\text { Without Halide } \\
\left(\mathrm{x} 10^{3}\right)\end{array}$ & $\begin{array}{l}\text { With Halide } \\
\left(\times 10^{-3}\right)\end{array}$ & $\begin{array}{l}\text { Without Halide } \\
\left(\times 10^{3}\right)\end{array}$ & $\begin{array}{l}\text { With Halide } \\
\left(\times 10^{-3}\right)\end{array}$ & $\begin{array}{l}\text { Without Halide } \\
\left(x 10^{3}\right)\end{array}$ & $\begin{array}{l}\text { With Halide } \\
\left(\times 10^{-3}\right)\end{array}$ \\
\hline $1.0 \mathrm{~g} / 0.1 \mathrm{M}$ & -0.806 & 4.30 & -0.42 & 10.91 & -0.1 & 13.66 \\
\hline $1.0 \mathrm{~g} / 0.2 \mathrm{M}$ & -1.56 & -11.20 & -1.38 & -7.45 & -1.15 & -5.15 \\
\hline $1.0 \mathrm{~g} / 0.3 \mathrm{M}$ & -2.22 & -20.58 & -2.08 & -18.36 & -1.93 & -15.98 \\
\hline $1.5 \mathrm{~g} / 0.1 \mathrm{M}$ & -1.23 & -5.76 & -0.94 & 2.13 & -0.42 & 6.19 \\
\hline $1.5 \mathrm{~g} / 0.2 \mathrm{M}$ & -1.84 & -14.54 & -1.61 & -11.97 & -1.37 & -8.25 \\
\hline $1.5 \mathrm{~g} / 0.3 \mathrm{M}$ & -2.42 & -23.32 & -2.21 & -21.28 & -2.07 & -19.10 \\
\hline $2.0 \mathrm{~g} / 0.1 \mathrm{M}$ & -1.56 & -9.88 & -1.38 & -6.39 & -0.86 & -2.06 \\
\hline $2.0 \mathrm{~g} / 0.2 \mathrm{M}$ & -2.07 & -18.11 & -1.85 & -15.43 & -1.56 & -12.11 \\
\hline $2.0 \mathrm{~g} / 0.3 \mathrm{M}$ & -2.59 & -24.14 & -2.37 & -21.82 & -2.20 & -20.11 \\
\hline
\end{tabular}

Table 4: Gibb's free energy $\left(\Delta \mathrm{G} / \mathrm{Jmol}^{-1}\right)$ for the adsorption of chromium onto orange peels as adsorbent.

\section{Effect of halides}

From table 1, comparing adsorption between initial solution without halides and that with halides revealed that adsorption decreases with the introduction of halides. This is as a result of the halides competing with the chromium ions for adsorption sites, thereby reducing their availability to the adsorption sites.

\section{Conclusions}

This work described the sorption of Chromium (III) ions from aqueous solution using orange peels in the absence and presence of halides. The experimental results of this study revealed that the maximum removal efficiency of Chromium ions occurred at initial $\mathrm{pH}$ of 2 and solution temperature of $30^{\circ} \mathrm{C}$. Also, the removal efficiency of Chromium (III) ions increases as the dosage of the adsorbent increases. The isotherm study indicated that, Freundlich isotherm best modeled the adsorption process for the two systems. The equilibrium removal of Chromium ions decreases as the temperature of solution increases; and as halides are being introduced due to competition between the ions for adsorption sites.

\section{References}

1. 1. Srivastava NK, Majumder CB (2008) Novel advances in environmental research, biofiltration methods for the treatment of heavy metals from industrial wastewater. Journal of Hazardous Materials 6: 533-40.

2. 2. SitiNur A, Aeisyah H, Mohd I, Shah K, Shamsu IL (2013) Adsorption process of heavy metals by low-cost adsorbent: A Review. World Applied Sciences Journal 28: 1518-1530.

3. 3. Bailey SE, Olin TJ, Bricka RM (1999) A Review of Potentially Low-Cost Sorbents for Heavy Metals. Water Research 33: 2469-2479.

4. 4. Dorris KL, Zhang Y, Shukla A (2000) The removal of heavy metal from aqueous solutions by sawdust adsorption- removal of copper. J Hazard Mater 80: 33-42.
5. 5. Gloaguen V, Morvan HJ (1997) Removal of heavy metal ions from aqueous solution by modified barks. Environmental Sci. Health 32: 901912.

6. 6. Dhungana B, Yadav V (2002) Determination of chromium in tannery effluent using adsorption of chromium (vi) on saw dust and charcoal from sugarcane bagasses spectrophotometric method using diphenylcarbazide. Journal of Nepal Chemical Society 23: 93-101.

7. 7. Cavaco SA, Fernandes SB (2007) Determination of chromium in industrial effluent using removal of chromium from electroplating industry effluents by ion exchange resins. Journal of Hazardous Materials 144: 634-638.

8. 8. Ayuba AM, Ladifa HM (2013) Kinetic studies of chromium amputation from aqueouus solution using citrus sinensis (orange) peel. Proceedings of the 36th Annual International Conference, Chemical Society of Nigeria 384-389.

9. 9. Su C, Suarez DL (2000) Selenite and selenate sorption on iron oxides: an infrared and electrophoretic study. Soil Sci. Soc. Am. J. 64: 101-111.

10. 10. Goldberg S (2002) Competitive adsorption of arsenate and arsenite on oxides and clay minerals. Soil Sci. Soc. Am. J. 66: 413-421.

11. 11. Sheng G, Xu S, Boyd SA (1999) A dual function organo clay sorbent for lead and chlorobenzene. Soil Sci. Soc. Am. J. 63: 73-78.

12. 12. Dada AO, Olalekan AP, Olatunya AM, Dada O (2012) Langmuir, Freundlich, Temkin and Dubinin-Radush Kevich isotherms studies of equilibrium sorption of $\mathrm{Zn} 2+$ onto phosphoric acid modified rice husk. IOSR Journal of Applied Chemistry 3: 38-45.

13. 13. Ladan M, Ayuba AM, Bishir U, Jamilu A, Habibu S (2013) Thermodynamic properties of chromium adsorption by sediments of river Watari, Kano State. Chemsearch Journal 4: 1-5.

14. 14. Lee JD (1996) Concise Inorganic Chemistry, fifth edition, Blackwell Science Ltd, France, 718-722.

15. 15. Amacher MC, Selim HM, Iskandar IK (1988) Kinetics of chromium (vi) and cadmium retention in soils: a nonlinear multireaction model. Soil Sci. Soc. Am. J. 52: 398-408.

16. 16. Jiang JQ, Cooper C, Ouki S (2002) Comparison of modified montmorillonite adsorbents-part 1: preparation, characterization and phenol adsorption. Chemosphere 47: 711-716 
Citation: Pam AA, Audu UF, Onakpa SA, Muhammad AA (2014) Thermodynamic Study of the Competitive Adsorption of Chromium (III) lons and Halides onto Sweet Orange (Citrus Sinensis) Peels as Adsorbent. J Environ Anal Chem 1: 114. doi:10.4172/JREAC.1000114

Page 7 of 7

17. 17. Taha MR, Ahmad K, Aziz AA, Chik Z (2009), London, UK 377-403

18. 18. Yang CH (1998) Statistical mechanical study on Freundlich isotherm equation. J. colloid interface sci. 208: 379-387.

19. 19. Almas AR, Salbu B, Singh BR (2000) Changes in partitioning of cadmium-109 and zinc- 65 in soil as affected by organic matter addition and temperature. Soil Sci. Soc. Am. J. 64: 1951-1958

20. 20. Saha UK, Liu C, Kozak LM, Huang PM (2004) Kinetics of selenite adsorption on hydroxyaluminium and hydroxyaluminosilicatemontmorillonite complexes. Soil sci. soc. Am. j. 68: 1197-1209.
21. 21. Balistrieri LS, Chao TT (1987) Selenium adsorption by Goethite. Soil Sci. Soc. Am. J. 51: 1145-1151.

22. 22. Mohammed A, Al-Anber (2010) Removal of high level Fe3+ from aqueous solution using Jordanian Inorganic materials: Bentonite and Quartz. Desalination 250: 885-891.

23. 23. Solener M, Tunali S, Ozcan AS, Ozcan A, Gedikbey T (2008) Adsorption characteristics of lead (ii) ions onto the clay/poly (methoxyethyl)acrylamide (PMEA) composite from aqueous solutions. Desalination 223: 308-322. 